\section{Cranberry in children: prevention of recurrent urinary tract infections and review of the literature}

\author{
Angelica Dessì, ${ }^{*}$, Alessandra Atzei, ${ }^{2}$ Vassilios Fanos ${ }^{1}$ \\ ${ }^{1}$ Department of Paediatrics, Neonatal Intensive Care Unit, Neonatal Pathology, \\ Puericultura Institute and Neonatal Section, University of Cagliari, Italy, \\ ${ }^{2}$ Department of Paediatrics, Neonatal Intensive Care Unit, Neonatal Pathology, \\ Puericultura Institute and Neonatal Section, Azienda Ospedaliero Universitaria, \\ University of Cagliari, Italy.
}

\begin{abstract}
Urinary tract infections (UTI) are common in childhood. In 30-50\% of children with UTI the infections occur recurrently, especially in those with vesicoureteral reflux (VUR), neurogenic bladder (NB), previous cystitis or pyelonephritis and malformative uropathies. To reduce the likelihood of UTI, antibiotic prophylaxis has been regarded as the therapeutic standard for many years. However, the disadvantage of long-term antibiotic therapy is the potential for development of collateral effects and resistant organisms in the host. Such reasons have induced scientists to search for alternative modalities of UTI prevention and have contributed to determining the increasing desire for "naturalness" of the population and preventing excessive medication. The use of cranberry fulfils these needs by potentially replacing or enhancing traditional procedures. The purpose of this study was to assess the effectiveness of cranberry in preventing UTI in pediatric populations. We searched Pubmed, the Cochrane Central Register of Controlled Trials and Internet. Cranberry in patients with previous UTI was evaluated in three studies, cranberry in patients with VUR in three studies and four studies analyzed the efficacy of cranberry in children with NB. In seven of nine studies cranberry had a significant effect in preventing UTI.
\end{abstract}

Revista Brasileira de Farmacognosia Brazilian Journal of Pharmacognosy 21(5): 807-813, Sep./Oct. 2011

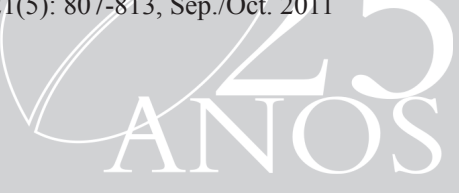

\section{Article}

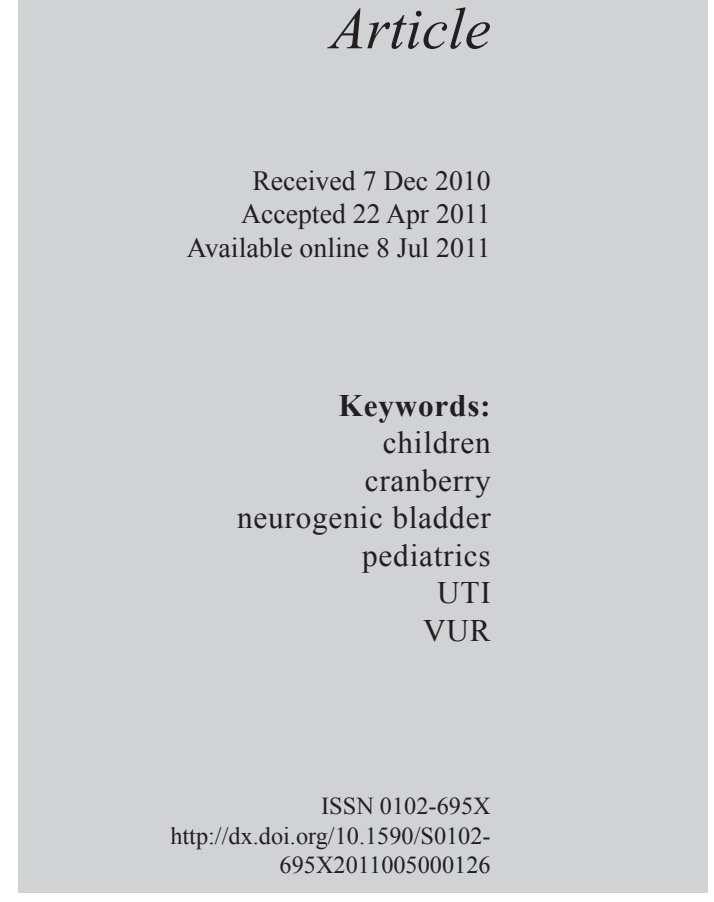

\section{Introduction}

Urinary tract infections (UTI) are the most frequent bacterial infections in pediatrics after infections of the respiratory tract: at the age of seven, $8 \%$ of females and $2 \%$ of males present with at least one episode of UTI. Only in the first three to six months is the incidence in males higher, after which the pathology appears more often in females. Children who have had a UTI run a 10 to $30 \%$ risk of recurrence and in $15 \%$ of cases may develop high blood pressure (Foxman et al., 2000).

A study carried out in all of Denmark showed that in one thousand patients in pediatric age followed for one year by an area physician there were nineteen episodes of UTI (Kwock et al., 2006). A 2006 study (Wald, 2006) showed that UTI represents the most frequent and serious bacterial infection in the United States since some bacterial infections ( $S$. pneumoniae and $H$. influenzae) have been weakened through vaccinations. From the aetiological standpoint the most common bacterium in discussion is E. coli (almost $80 \%$ of cases) and more rarely other enterobacteria, especially Proteus spp. (mostly in males), Klebsiella spp., Enterococcus spp., Citrobacter spp., Providencia spp., Morganella spp., Serratia spp. and Salmonella spp., which, similarly to the strains of Pseudomonas spp. with low virulence, may be involved in complicated infections.

In the first months of life, UTI, especially relapsing (infections caused by the same germ) and recurrent (UTI caused by different microorganisms), represent an important clinical element for further investigations and diagnoses of possible urinary tract malformations. Indeed, in children there are factors that favor relapses and/or recurrences of UTI such as malformative uropathies, especially obstructive; vesicoureteral reflux (VUR), previous repeated episodes of cystitis and/or pyelonephritis (three or more episodes per year) even without urinary tract anomalies and the frequently catheterized neurogenic bladder (NB) (Mangiarotti et al., 2000).

Although the literature supplies no univocal indications, in the pediatric age it is common practice to use antibiotic prophylaxis in the treatment of relapsing and recurrent UTI, especially in patients with 
VUR (Fanos \& Cataldi, 2004). However, the many side effects of antibiotics, the increasing number of antibiotic-resistant bacteria and the economic impact of the therapy have promoted research on alternative measures to prevent UTI. An important contribution to this research has come from the ever-increasing desire for "natural remedies" among the population as concerns the excessive (or perceived as such) use of drugs in special periods of life, such as pregnancy and infancy (Fanos et al., 2006a).

The use of cranberry (Vaccinium macrocarpon Ainton, Ericaceae) juice represents one of the possible solutions that may potentially go hand in hand with traditional procedures or, in some cases, even replace them.

\section{What do we know about the cranberry?}

\section{Historical notes}

The interest in cranberry juice goes back to the times of the American colonies. The traditional use of the cranberry is associated with Thanksgiving Day starting from 1961 when the pilgrims served it with turkey and lobster (Kemper, 1999). The common name cranberry comes from the colonial name of crane berry, which later became contracted. The withered flower resembles the neck and head of the sandhill crane, which the colonists often saw feeding on this fruit.

It was appreciated by the North American natives owing to its beneficial effects both in the diet (as a sweetener or in the drying of meat and fish) and as a remedy in disinfecting wounds, reducing pain caused by indigestion and in oral and dental hygiene. The Penobscot tribe in Maine used the cranberry for treating kidney stones and other urinary problems (Duthie et al., 2005). In East Europe it was used as an antipyretic and anticancer remedy and, being rich in vitamin $C$, it was loaded on ships to prevent scurvy. Used as a folk remedy for UTI before the introduction of antibiotics, it continues to be widely used for this purpose (Kemper, 1999); in 1997 it was one of the ten most sold herbal remedies in the United States (Reid \& Bruce, 2003). The part used for this purpose is the mature berry, which is extremely bitter so that many preparations are sweetened to improve their taste.

\section{Main components and how it acts}

The main components of the cranberry are flavonoids (among which the anthocyanins), catechins, triterpenoids, organic acids (butyric, malic, glucuronic, citric and quinic), vitamins (A and $\mathrm{C}$ ), carbohydrates (especially fructose), mineral salts and tannins such as the proanthocyanidins (PAC) (characteristic of type
A).

This plant has recently been monographed in the ESCOP (ESCOP, 2009) where we find a liquid preparation in compliance with the United States Pharmacopoeia with no less than $2.4 \%$ of dextrose, $0.7 \%$ of fructose, $0.9 \%$ of quinic acid, $0.9 \%$ of citric acid and $0.7 \%$ of malic acid. The recommended preparation is the concentrated juice extract titrated in proanthocyanidin of type A at 1.2 to $1.4 \%$ (or polyphenols at $15 \%$ ).

For a long time the antiseptic and antibacterial action of the cranberry was attributed to its capacity to acidify the urine owing to its vitamin $\mathrm{C}$ content and its capacity to metabolize benzoic acid into hippuric acid with antibacterial properties. More recent pharmacological studies have also revealed that cranberry juice is capable of inhibiting the adhesion of type 1 (activity attributed to fructose) and type $\mathrm{P}$ (activity attributed to the proanthocyanidins) fimbriated $E$. coli to the epithelial cells of the bladder wall (Zafriri et al.,1989; Ahuja et al., 1998; Howell et al., 2010). In fact, the pathogenicity of these bacteria is connected to the presence of fimbriae at the extremities of which there are proteinic structures called adhesins which make it possible for the pathogens to adhere to the membrane of uroepthelial cells. The type A proanthocyanidins appear to be those mainly responsible for the antiseptic and antibacterial action. In a study by Howell \& Foxman. (2002) the antiadhesive activity of the cranberry against type B uropathogen fimbriated $E$. coli was studied in vitro by examining PAC A, which has been shown to inhibit adhesion (Howell \& Foxman, 2002). PAC, by acting as receptor analogues and adhering to the extremities of the fimbriae, competitively inhibit the adhesion of $E$. coli, thus causing an elongated deformation of the bacterium cell bodies, a reduction in the length and density of the P-fimbriae and finally an inhibition of their synthesis with the total disappearance of the adhesins. The antiadhesive activities of the cranberry help to prevent UTI also indirectly by selecting at the intestinal level less adhesive uropathogenic bacteria. A study in 2005 showed in subjects who regularly drank cranberry juice an increase in urinary salicylicates, thus suggesting a possible local anti-inflammatory effect and a further probable mechanism of action (Duthie et al., 2005). The research demonstrated that besides the urinary antiseptic action, the cranberry possesses an antioxidant and radical scavenger (being rich in polyphenols) activity and an antibacterial action against many germs (recently it has been demonstrated as acting against $H$. pylori and S. mutans) (Gotteland et al., 2008; Koo et al., 2010).

\section{Clinical studies in the adult}

There are numerous studies in the literature concerning the use of the cranberry in the adult which provide data that confirm the therapeutic action of this plant in the prevention of UTI. 
A double-blind randomized placebo-controlled cross-over trial on twenty healthy volunteers showed a significant dose-dependent reduction of bacterial adhesiveness following the administration of cranberry (Di Martino, 2006).

The Cochrane group has recently demonstrated a significant reduction in UTI in women following the regular assumption of cranberry juice (Jepson \& Craig, 2008). The study included consultation of databases, the involvement of companies producing products based on the cranberry and the search for lists of bibliographic references of systematic revisions and important studies. All controlled and randomized studies on cranberry-based products used in the prevention of UTI were examined and studies on patients of both sexes and different ages were included. The authors concluded that there is definite evidence that cranberry juice can be effective in reducing the number of symptomatic urinary tract infections in females after twelve months of treatment. However, certainties are lacking as concerns its pharmaceutical preparation and the most appropriate dosages, and finally there are no clinical studies in support of the fact that the cranberry is just as effective in the pediatric age. The most recent study has demonstrated that besides E. coli, the cranberry can significantly reduce the adherence of other common pathogens of the urinary tract, including $P$. mirabilis, $S$. aureus, K. pneumoniae, Enterobacter and P. aeruginosa (Magariños et al., 2008).

\section{Dosage and side effects}

The daily dose recommended in ESCOP Monographs (ESCOP, 2009) is in adults 300 to 750 $\mathrm{mLl} /$ day of a liquid preparation containing 25 to $100 \%$ juice in two to three administrations or 200 to 500 $\mathrm{mg} /$ day of dry extract or concentrated juice in two daily administrations. As concerns children between the ages of two and eighteen, $15 \mathrm{~mL} / \mathrm{kg}$ of juice or equivalent doses are recommended. No limits on use in the pediatric age are reported (some studies included breastfeeding infants a few months after birth).

The cranberry is normally well tolerated. In a study by Kontiokari et al. (2005) in 341 children cranberry juice appeared to have beneficial effects on urinary health and this was not compromised by other unexpected antimicrobic effects (Kontiokari et al., 2005).

A significant increase in the urinary concentration of oxalates (controversial finding) was reported and this suggests caution in patients predisposed for the formation of urinary oxalate stones (Gettman et al., 2005). Against this, the cranberry has a protective effect on the formation of urate stones. A single case of autoimmune thrombocytopenic purpura was reported in the case of an elderly patient (Davies et al., 2001) and a probable interaction between cranberry and warfarin in anticoagulant therapy (Suvarna et al., 2003) has also been described. The product obviously cannot be administered to patients allergic to cranberry. As concerns the use of cranberry in pregnancy, in Italy this was expressly prohibited by a decree law in 2002 (Official Gazette no.167 of 18 July 2002), concerning the use of products containing biflavonoids. It is to be pointed out that this is an isolated provision, but one that has recently been confirmed by the Supplement to the ESCOP Monographs 2009 (ESCOP, 2009) which states that in pregnancy the administration must be under the control of a physician whenever the dose greatly exceeds the amount found in foodstuffs. The recommendation is extended to the period of breastfeeding. On this subject, the data in a study by Wing et al. (2008) in California on 188 women below the sixteenth week of pregnancy demonstrated that there may be a protective effect in the assumption of cranberry against asymptomatic bacteriuria and UTI in pregnancy (Wing et al., 2008).

As concerns costs, these were analyzed in a controlled clinical study that evaluated the effects of different cranberry-based preparations on UTI in women. One hundred and fifty sexually active women between the ages of 21 and 72 were enrolled; they assumed per os $150 \mathrm{mg}$ of dry cranberry extract or 250 $\mathrm{mL}$ of cranberry juice or a placebo for one year. The assessment was made on the basis of the number of cystitis episodes and the consumption of antibiotics during the year of the study. At the end of the study it was found that both the dry extract and the juice reduced the number of infections by 20 and $18 \%$ respectively. The yearly cost of the therapy was 624 USD for the dry extract and 1400 USD for the juice. The consumption of antibiotics was significantly lower in the two verum groups compared to the placebo group. The study indicates that both the dry extract and the juice of cranberry are effective in UTI, although the dry extract is preferable from the economic standpoint (Stothers, 2002).

\section{The cranberry in the child}

\section{Materials and methods}

Studies on the use of cranberry in the pediatric age are few; however, the literature shows an everincreasing interest in its use in this delicate age. This is supported by results obtained in adults, by the documented scarcity of side effects, by the ease in administration and the fair and verified compliance by the patients treated.

The purpose of this research was to evaluate the efficacy of cranberry juice in the prevention of UTI 
in pediatrics through a review of the entire literature. We searched through Pubmed, Embase, the Cochrane Central Register of Controlled Trials (Central Cochrane Library) and Internet and examined the proceedings of international congresses and the review bibliography. Information was collected on methods, researchers, patients, operations, drugs administered, side effects, compliance with therapy and results. The study, considering the few works now available, included all written publications which were analyzed by type of study (retrospective study, randomised controlled trials etc.) (Table 1).

\section{Results and Discussion}

Recent studies affirm that the use of antibiotic prophylaxis in children with relapses of UTI is not only ineffective in preventing infection and long-term kidney damage, but is also associated with important side effects. A very recent meta-analysis involving five studies revealed no or little benefit with prophylaxis in the prevention of UTI recurrence (Mattoo, 2010). Also to be considered is the result of a study by Smolkin et al. (2007): one out of two couples does not perform the long-term (e.g. one year) antibiotic prophylaxis prescribed by specialists and $50 \%$ of parents cannot explain why they perform antibiotic prophylaxis even though this has been explained to them (Smolkin et al., 2007). It is also of interest to note that in a Unites States study, about $30 \%$ of parents administered cranberry to their children to prevent UTI, but only $25 \%$ of them spoke to their physician about this (Super et al., 2005).

Table 1. Summary of clinical trials on cranberry products for UTI prophylaxis in children.

\begin{tabular}{|c|c|c|c|c|c|c|}
\hline Study & $\begin{array}{l}\text { Year of } \\
\text { study }\end{array}$ & Patients & $\begin{array}{l}\text { Mean age } \\
\text { (months) }\end{array}$ & Type of study & Intervention & Outcome \\
\hline Bircan et al. & 2010 & $\begin{array}{c}50(16 \mathrm{M}-34 \mathrm{~F}) \text { with NB } \\
\text { (32 overactive detrusor/18 } \\
\text { hypocompliant bladder) }\end{array}$ & $84.9 \pm 51.4$ & $\begin{array}{l}\text { Retrospective } \\
\text { study }\end{array}$ & $\begin{array}{c}\text { Cranberry } 1 \text { capsule/ } \\
\text { day for } 25.94 \pm 24.12 \\
\text { months }\end{array}$ & $\begin{array}{c}\text { A significant reduction in UTI } \\
(4.36 / \text { year }) \\
\text { in overall group }\end{array}$ \\
\hline Goj et al. & 2010 & 63 (24M-39F) with VUR & 20 & $\begin{array}{l}\text { Retrospective } \\
\text { study }\end{array}$ & $\begin{array}{c}\text { Cranberry concentrate } \\
0.5 \mathrm{~mL} / \mathrm{kg} \text { daily; } 24 \\
\text { month trial }\end{array}$ & $\begin{array}{c}\text { A significant reduction in UTI } \\
(4.7 \%) \text { in patients with VUR, } \\
\text { including high grade VUR } \\
\text { and associated urinary tract } \\
\text { malformations }\end{array}$ \\
\hline $\begin{array}{l}\text { Maringhini } \\
\text { et al. }\end{array}$ & 2010 & $\begin{array}{c}79(23 \mathrm{M}-56 \mathrm{~F}) \text { with } \\
\text { previous UTI }\end{array}$ & 62.4 & $\begin{array}{l}\text { Retrospective } \\
\text { study }\end{array}$ & $\begin{array}{l}\text { Cranberry concentrate } \\
0.5 \mathrm{~mL} / \mathrm{kg} \text { daily in } \\
\text { two doses for a mean } \\
\text { of } 6.4 \text { months }\end{array}$ & $\begin{array}{l}\text { UTI average rate during } \\
\text { treatment was } 0.03 / \text { month } \\
\text { compared with } 0.4 / \text { month in } \\
\text { the preceding period }\end{array}$ \\
\hline $\begin{array}{l}\text { Ferrara et } \\
\text { al. }\end{array}$ & 2009 & $84 \mathrm{~F}$ with previous UTI & 90 & $\begin{array}{l}\text { Randomized } \\
\text { controlled trial }\end{array}$ & $\begin{array}{c}\text { Cranberry juice } \\
\text { (C.J.) } 50 \mathrm{~mL} \text { daily } v s \\
\text { Lactobacillus (L.) GG } \\
\text { drink on five days a } \\
\text { month/vs controls; six } \\
\text { month trial }\end{array}$ & $\begin{array}{l}\text { A significant reduction in } \\
\text { UTI: } 18.5 \% \text { for C.J. vs } 42.3 \% \\
\text { for L.GG vs } 48.1 \% \text { for } \\
\text { controls }\end{array}$ \\
\hline $\begin{array}{l}\text { Nishizaki } \\
\text { et al. }\end{array}$ & 2009 & 31 (18M-13F) with VUR & $\begin{array}{l}32.5 \pm 19.6 \\
\text { (C.J.) } \\
18.2 \pm 22.9 \\
\text { (Cefaclor) }\end{array}$ & $\begin{array}{l}\text { Randomized } \\
\text { controlled trial }\end{array}$ & $\begin{array}{c}\text { Cranberry juice (C.J.) } \\
100 \mathrm{~mL} \text { daily } v s \\
\text { Cefaclor } 5-10 \mathrm{mg} / \mathrm{kg} / \\
\text { day; for } 17.2 \pm 7.90 \\
\text { (C.J.) and } 10.2 \pm 3.29 \\
\text { (Cefaclor) months }\end{array}$ & $\begin{array}{l}\text { No significant difference in } \\
\text { the risk of having recurrent } \\
\text { UTI between the cranberry } \\
\text { and cefaclor groups }(p>0.05)\end{array}$ \\
\hline Fanos et al. & $2006 b$ & $\begin{array}{c}20(4 \mathrm{M}-16 \mathrm{~F}) \text { with previous } \\
\text { UTI }\end{array}$ & $85.2 \pm 52.3$ & $\begin{array}{l}\text { Retrospective } \\
\text { study }\end{array}$ & $\begin{array}{l}\text { Cranberry } 1 \text { capsule/ } \\
\text { day for } 2.8 \pm 10 \text { months }\end{array}$ & $0.36 \% \mathrm{UTI} /$ patient/year \\
\hline $\begin{array}{l}\text { Erculiani } \\
\text { et al. }\end{array}$ & 2004 & $\begin{array}{c}47(25 \mathrm{M}-22 \mathrm{~F}) \text { with NB and/ } \\
\text { or VUR }\end{array}$ & $\begin{array}{c}\text { Between } \\
24 \text { and } 168\end{array}$ & $\begin{array}{l}\text { Retrospective } \\
\text { study }\end{array}$ & $\begin{array}{l}\text { Cranberry } 2 \text { capsule/ } \\
\text { day for } 11.2 \text { months }\end{array}$ & $\begin{array}{c}\text { Cranberry appears to have } \\
\text { beneficial effects in patients } \\
\text { with low grade VUR }\end{array}$ \\
\hline $\begin{array}{l}\text { Schlager } \\
\text { et al. }\end{array}$ & 1999 & 15 children with NB & $\begin{array}{c}\text { Between } \\
24 \text { and } 216\end{array}$ & $\begin{array}{l}\text { Double-blind } \\
\text { placebo- } \\
\text { controlled } \\
\text { cross-over } \\
\text { study }\end{array}$ & $\begin{array}{c}300 \mathrm{~mL} \text { cranberry } \\
\text { concentrate vs } \\
\text { placebo, each for three } \\
\text { months }\end{array}$ & $\begin{array}{c}\text { No benefit in preventing UTI } \\
\text { or bacteriuria }\end{array}$ \\
\hline Foda et al. & 1995 & $\begin{array}{l}40 \text { children with NB } \\
\text { (21 finished) }\end{array}$ & - & $\begin{array}{l}\text { Randomized } \\
\text { single-blind } \\
\text { cross-over } \\
\text { study }\end{array}$ & $\begin{array}{l}\text { Cranberry cocktail } 15 \\
\mathrm{~mL} / \mathrm{kg} \text { /day vs water, } \\
\text { each for six months }\end{array}$ & $\begin{array}{c}\text { No benefit in preventing UTI } \\
\text { or bacteriuria }\end{array}$ \\
\hline
\end{tabular}


They explained this by saying that since the product was natural it was by definition without side effects and also because they thought physicians knew very little about the subject.

Recent literature offers works with promising results on the use of cranberry in the prevention of UTI in the pediatric age; despite the difficulty of performing a comparative evaluation of the different studies owing to the heterogeneity of the populations, the use of different preparations containing cranberry (concentrated juice, juice, cocktails, capsules and so on) at different dosages, but in any case the data appear encouraging.

Nine studies were included in this review. Some studies were not included in the meta-analyses due to methodological issues or lack of available data. Cranberry in patients with previous UTI was evaluated in three studies, cranberry in patients with VUR in three studies and four studies analyzed the efficacy of cranberry in children with NB (one study assessed both VUR and NB). While Foda (Foda et al., 1995) and Schalager (Schalager et al., 1999) found no effect on the reduction of bacteriuria in children affected by NB treated with cranberry, a subsequent study by Erculiani et al. (2004) on a group of 47 children with the same pathology found favorable results (Erculiani et al., 2004) as in all other works written to date (Table 1). In a preliminary study by one of the authors (Fanos et al., 2006b), twenty children were placed in prophylaxis with a special extract of cranberry having a high content of phenols with vitamin $\mathrm{C}$ for the purpose of evaluating the possible use of cranberry in the prevention of UTI in children. During the prophylaxis only three episodes of UTI were found in different patients, for which the cranberry therapy was suspended. In the remaining seventeen patients the treatment was well tolerated and no side effects were reported. Various studies have compared the use of cranberry juice in the prophylaxis of UTI with the administration of a placebo, Lactobacillus GG and antibiotic prophylaxis. In a recent work by Ferrara et al. (2009) 84 girls aged from 3 to 14 years with UTI were studied: they were divided into three groups which received three different treatments: G1 (cranberry juice $50 \mathrm{~mL} /$ day), G2 (Lactobacillus GG $100 \mathrm{~mL} / 5$ days per month) and G3 (controls). The first group presented five episodes of UTI (18.5\%) against $11(42.3 \%)$ and $18(48.1 \%)$ episodes in groups G2 and G3 respectively (Ferrara et al., 2009). Only one work (Nishizaki et al., 2009) compared the effect of cranberry with that of an antibiotic (Cefaclor) in UTI prophylaxis. This study shows that the effect and efficacy of the two treatments are comparable and without the presence of side effects caused by cranberry juice (Nishizaki et al., 2009). The latest works in 2010 were published in abstract form in the proceedings of the Fifteenth
Congress of the International Pediatric Nephrology Association. They deal with the cranberry treatment of three types of different patients: with VUR (Goj et al., 2010), NB (Bircan et al., 2010) and previous UTI (Maringhini et al., 2010). All three of these works report significantly positive results with the use of cranberry in UTI prevention.

In the site of the United States National Health Institute (ClinicalTrials.gov) we found four studies (three completed and one recruiting) concerning cranberry in children, but no results have been published to date (Uhari, 2009; Godbolt, 2010; Anderson, 2006; Wing, 2006). Some of these authors are studying the interaction between the antibiotic and the cranberry in acute UTI.

In all works examined, the cranberry was well tolerated and there was good compliance both by patients and parents. We must indicate the critical points in this review: the scarcity of data, the heterogeneity of case histories as concerns the population studied, the types of products, their dosage and the duration of treatment.

\section{Conclusions}

Recurrent and relapsing UTI are quite common. Their frequent finding in given age groups, such as infancy, indicate the need to find a therapy that is the least invasive possible and one without side effects. The data in pediatric literature, although few and not definitive, provide encouraging results. The cranberry may be a possible valid alternative to traditional antibiotic prophylaxis, which today is under strong attack. Together with the good tolerability of cranberry there is also good patient and parent compliance as concerns the use of this natural element with proven special characteristics. The potential uses of the cranberry are in cases of: a) documented relapsing and recurrent cystitis once organic causes (e.g. VUR) have been excluded, b) breastfeeding children of three to six months with grade 1 and 2 reflux, normal ultrasonography and with careful, informed and cooperating parents, c) association with the antibiotic in the treatment of acute UTI (in the near future). The results of the studies analyzed may make it possible for pediatricians to take the cranberry into consideration in cases of this kind since its use does not lead to a risk of antimicrobial resistance and to date no side effects have been associated with it in pediatric patients.

In any case, further studies are propitious so as to confirm the efficacy and tolerability in the pediatric age.

\section{References}

Ahuja S, Kaack B, Roberts J 1998. Loss of fimbrial adhesion with the addition of Vaccinum macrocarpon to the 
growth medium of P-fimbriated Escherichia coli. $J$ Urol 159: 559-562.

Anderson GD 2006. Interactions between cranberry juice and antibiotics used to treat urinary tract infections. http://clinicaltrials.gov/ct2/show?term $=$ cranberry $+\mathrm{ch}$ ildren\&rank $=3$, accessed in November 2010.

Bircan Z, Mutlu H, Tanriverdi S, Ozkurkcugil C 2010. Do cranberry capsules prevent recurrent urinary tract infection in children with neurogenic bladder? Pediatr Nephrol 25: 1848.

Davies JK, Ahktar N, Ranasinge E 2001. A juicy problem. Lancet 358: 2126.

Di Martino P, Agniel R, David K, Templer C, Gaillard JL, Denys P, Botto H 2006. Reduction of Escherichia coli adherence to uroepithelial bladder cells after consumption of cranberry juice: a double-blind randomized placebo controlled cross-over trial. World J Urol 24: 21-27.

Duthie GG, Kyle JA, Jenkinson AM, Duthie SJ, Baxter GJ, Paterson JR 2005. Increased salicylate concentrations in urine of human volunteers after consumption of cranberry juice. J Agric Food Chem 53: 2897-2900.

Erculiani E, Giacomello L, Cecchetto M, Corroppolo M, Camoglio FS, Ottolenghi A 2004. Report preliminare sulla validità dell'estratto speciale di cranberry ad alta titolazione in polifenoli con vitamina $\mathrm{C}$ nella prevenzione delle IVU da E. Coli in bambini con severe uropatie. XX Congresso Nazionale Società Italiana di Nefrologia Pediatrica. Napoli, Italia.

ESCOP 2009. ESCOP Monographs: The Scientific Foundation for Herbal Medicinal Products. $2^{\text {nd }}$ edition Supp. 2009.

Fanos V, Atzei A, Zaffanello M, Piras A, Cataldi L 2006a. Cranberry and prevention of urinary tract infections in children. $J$ Chemother 3: 21-24.

Fanos V, Cataldi L 2004. Antibiotics or surgery for vesicoureteral reflux in children. Lancet 364: 17201722.

Fanos V, Piras A, Atzei A 2006b. Prevenzione delle infezioni urinarie e fitoterapia: il Cranberry (mirtillo). Fitoscienza 3: 5-9.

Ferrara P, Romaniello L, Vitelli O, Gatto A, Serva M, Cataldi L 2009. Cranberry juice for the prevention of recurrent urinary tract infections: a randomized controlled trial in children. Scand J Urol Nephrol 43: 369-372.

Foda MM, Middlebrook PF, Gatfield CT, Potvin G, Wells G, Schillinger JF 1995. Efficacy of cranberry in prevention of urinary tract infection in a susceptible pediatric population. Can J Urol 2: 98-102.

Foxman B, Barlow R, D’Arcy H, Gillespie B, Sobel JD 2000. Urinary tract infection: self-reported incidence and associated costs. Ann Epidemiol 10: 509-515.

Gettman MT, Ogan K, Brinkley LJ, Adams-Huet B, Pak CY, Pearle MS 2005. Effect of cranberry juice consumption on urinary stone risk factors. J Urol 174: 590-594.

Godbolt AK 2010. Effect of cranberry capsules on urinary infection rates in spinal cord injured patients during post acute rehabilitation. http://clinicaltrials.gov/ct2/ show/NCT01079169? term $=$ cranberry + children\&rank $=2$, accessed in November 2010 .

Goj V, Bernardo L, Masnata G 2010. Vesicoureteral reflux
(VUR): The role of cranberry prophylaxis. Pediatr Nephrol 25: 1851.

Gotteland M, Andrews M, Toledo M, Muñoz L, Caceres P, Anziani A, Wittig E, Speisky H, Salazar G 2008. Modulation of Helicobacter pylori colonization with cranberry juice and Lactobacillus johnsonii Lal in children. Nutrition 24: 421-426.

Howell AB, Botto H, Combescure C, Blanc-Potard AB, Gausa L, Matsumoto T, Tenke P, Sotto A, Lavigne JP 2010. Dosage effect on uropathogenic Escherichia coli antiadhesion activity in urine following consumption of cranberry powder standardized for proanthocyanidin content: a multicentric randomized double blind study. BMC Infect Dis 14: 10-94.

Howell AB, Foxman B 2002. Cranberry juice and adhesion of antibiotic-resistant uropathogens. JAMA 287: 30823083.

Jepson RG, Craig JC 2008. Cranberries for preventing urinary tract infections. Cochrane Database Syst Rev 23: CD001321.

Kemper KJ 1999. Cranberry (Vaccinium macrocarpon). http://www.longwoodherbal.org/cranberry/cranberry. pdf, accessed in November 2010.

Kontiokari T, Salo J, Eerola E, Uhari M 2005. Cranberry juice and bacterial colonization in children-a placebocontrolled randomized trial. Clin Nutr 24: 10651072.

Koo H, Duarte S, Murata RM, Scott-Anne K, Gregoire S, Watson GE, Singh AP, Vorsa N 2010. Influence of cranberry proanthocyanidins on formation of biofilms by Streptococcus mutans on saliva-coated apatitic surface and on dental caries development in vivo. Caries Res 44: 116-126.

Kwok WY, de Kwaadsteniet MC, Harmsen M, van SuijlekomSmit LW, Schellevis FG, van der Wouden JC 2006. Incidence rates and management of urinary tract infections among children in Dutch general practice: results from a nationwide registration study. $B M C$ Pediatr 6: 10.

Magariños HL, Sahr C, Selaive SD, Costa ME, Figuerola FE, Pizarro OA 2008. In vitro inhibitory effect of cranberry (Vaccinium macrocarpom Ait.) juice on pathogenic microorganisms. Prikl Biokhim Mikrobiol 44: 333-336.

Mangiarotti P, Pizzini C, Fanos V 2000. Antibiotic prophylaxis in children with relapsing urinary tract infections. $J$ Chemother 12: 115-123.

Maringhini SS, Costa AA, Migliore VV, Pavone GG, Leone FF, Corrado CC, Cusumano RR 2010. Cranberry in children with recurrent urinary tract infections. Pediatr Nephrol 25: 1854.

Mattoo TK 2010. Evidence for and against urinary prophylaxis in vesicoureteral reflux. Pediatr Nephrol 25: 23792382.

Nishizaki N, Someya T, Hirano D, Fujinaga S, Ohtomo Y, Shimizu T, Kaneko K 2009. Can cranberry juice be a substitute for cefaclor prophylaxis in children with vesicoureteral reflux? Pediatr Int 51: 433-434.

Reid G, Bruce AW 2003. Urogenital infections in women: can probiotics help? Postgrad Med J 79: 428-432.

Schlager TA, Anderson S, Trudell J, Hendley JO 1999. 
Effect of cranberry juice on bacteriuria in children with neurogenic bladder receiving intermittent catheterization. J Pediatr 135: 698-702.

Smolkin V, Halevy R, Sakran W, Kennes Y, Koren A 2007. Compliance with antibiotic prophylaxis in urinary tract infection in children. Pediatr Nephrol 22: 1451.

Stothers L 2002. A randomized trial to evaluate effectiveness and cost effectiveness of naturopathic cranberry products as prophylaxis against urinary tract infection in women. Can J Urol 9: 1558-1562.

Super EA, Kemper KJ, Woods C, Nagaraj S 2005. Cranberry use among pediatric nephrology patients. Ambul Pediatr 5: 249-252.

Suvarna R, Pirmohamed M, Henderson L 2003. Possible interaction between warfarin and cranberry juice. BMJ 327: 1454.

Uhari M 2009. Cranberry Juice in the Prevention of Urinary Tract Infections in Children. http://clinicaltrials.gov/ ct2/show/NCT00638170?term $=$ cranberry+children\&r ank $=1$, accessed on November 2010.

Wald ER 2006. Vesicoureteral reflux: the role of antibiotic prophylaxis. Pediatrics 117: 919-922.

Wing DA 2006. Cranberry juice for preventing bacteria in urine during pregnancy. http://clinicaltrials.gov/ct2/ show? term $=$ cranberry + children $\&$ rank $=4$, accessed in November 2010.

Wing DA, Rumney PJ, Preslicka CW, Chung JH 2008. Daily cranberry juice for the prevention of asymptomatic bacteriuria in pregnancy: a randomized, controlled pilot study. J Urol 180: 1367-1372.

Zafriri D, Ofek I, Adar R, Pocino M, Sharon N 1989. Inhibitory activity of cranberry juice on adherence of type 1 and type P fimbriated Escherichia coli to eucaryotic cells. Antimicrob Agents Chemother 33: 92-98.

\section{*Correspondence}

Angelica Dessì

NICU, Puericultura Institute and Neonatal Section, University of Cagliari

Via Ospedale 119, 09124 Cagliari, Italy

baire@unica.it

Tel/fax: +390706093495 